\title{
MAKNA DAN KETERLIBATAN ORANG KRISTEN DALAM RITUAL PUNDUK SAHUR PADA MASA COVID-19 DI DESA TUMBANG TAMBIRAH, KALIMANTAN TENGAH: KAJIAN SOSIO-TEOLOGIS
}

\section{THE MEANING AND INVOLVEMENT OF CHRISTIANS ON THE PUNDUK SAHUR RITUAL DURING COVID-19 IN TUMBANG TAMBIRAH VILLAGE, CENTRAL KALIMANTAN: A SOCIO-TEOLOGICAL STUDY}

\author{
Isabella Jeniva \\ Institut Agama Kristen Negeri Palangka Raya, Indonesia \\ isabellajeniva@gmail.com \\ Yolantya Widyasari \\ Institut Agama Kristen Negeri Palangka Raya, Indonesia \\ yolantya@stakn-palangkaraya.ac.id
}

Artikel diterima 01 Mei 2021, diseleksi 25 Mei 2021, dan disetujui 23 Juni 2021

DOI: https://doi.org/10.32488/harmoni.v20i1.481

\begin{abstract}
The Punduk Sahur ritual is one of the religious rituals of the Kaharingan tribe which aims to gain welfare and protection from the Dayak ancestors, which is believed to be able to keep the Dayak community away from dangers such as disease outbreaks. Surprisingly, in Tumbang Tambirah Village, Christians are also involved in carrying out the Punduk Sahur ritual and believe that through this ritual they can avoid the Covid-19 outbreak. The approach used in this research is qualitative method and descriptive type. Data collection techniques that will be used, namely the technique of observation, interviews, and literature study. This study applies a socio-theological study that aims to find out and describe how the process of organizing the Punduk Sahur ritual in the midst of the COVID-19 outbreak for the people of Tumbang Tambirah Village, and what factors are the involvement of Christians in the Punduk Sahur ritual in the midst of the COVID-19 outbreak in Tumbang Village. Tambirah, Central Kalimantan. This study found a finding that it can be concluded that Christians in Tumbang Tambirah Village take a dualistic attitude in the relationship between Christ and Culture.
\end{abstract}

Keywords: Rituals, Punduk Sahur, Christians, Covid-19.

\begin{abstract}
Abstrak
Ritual Punduk Sahur merupakan salah satu ritual agama suku Kaharingan yang bertujuan untuk mendapatkan kesejahteraan dan perlindungan dari leluhur Dayak, yang di percaya dapat menjauhkan masyarakat Dayak dari marabahaya seperti wabah penyakit. Anehnya, di Desa Tumbang Tambirah orang Kristen juga terlibat dalam pelaksanaan ritual Punduk Sahur serta menyakini bahwa melalui ritual tersebut mereka dapat terhindar dari wabah Covid-19. Pendekatan yang digunakan dalam penelitian ini adalah metode kualitatif dan jenis deskriptif. Teknik Pengambilan data yang akan digunakan, yaitu dengan teknik observasi, wawancara, dan studi pustaka. Penelitian ini menerapkan kajian sosioteologis yang bertujuan untuk mengetahui dan mendeskripsikan bagaimana proses penyelenggaraan ritual Punduk Sahur di tengah wabah COVID-19 bagi masyarakat Desa Tumbang Tambirah, dan apa faktor keterlibatan orang Kristen dalam ritual Punduk Sahur di tengah wabah COVID-19 di Desa Tumbang Tambirah, Kalimantan Tengah. Penelitian ini mendapatkan sebuah temuan yang dapat disimpulkan bahwa orang Kristen di Desa Tumbang Tambirah mengambil suatu
\end{abstract}


sikap dualis dalam hubungan Kristus dan Kebudayaan.

Kata Kunci: Ritual, Punduk Sahur, Orang Kristen, Covid-19

\section{PENDAHULUAN}

Wabah COVID-19 tidak hanya merubah tata sosial, budaya, dan sistem pendidikan pada masyarakat, tetapi juga merubah tata cara manusia berhubungan dengan Tuhan. Oleh karena itu Wabah COVID-19 juga berdampak dalam kehidupan seluruh umat beragama, tak terkecuali umat beragama yang ada di Kalimantan Tengah, baik yang beragama Kristen, Islam, Hindu dan Budha, yang telah merubah tata cara ibadahnya dengan tidak lagi melaksanakan peribadatan di rumah-rumah ibadat melainkan di rumahnya masing-masing bersama keluarga. Tidak hanya berpengaruh pada tata cara beribadah, wabah COVID-19 juga berpengaruh terhadap psikis dan spiritual setiap orang.

Kekhawatiran dan ketakutan masyarakat terhadap wabah COVID-19 menyebabkan banyak orang berupaya kembali membangun hubungan yang harmonis dengan Tuhan karna mereka menyadari situasi ini berada diluar kendali manusia. Ditengah mewabahnya COVID-19, totalitas iman manusia tidak lagi diukur melalui seberapa seringnya manusia pergi kerumah ibadat, melainkan bagaimana manusia mampu menghadapi situasi sulit dan genting terkait musibah yang dihadapinya dan menyakini bahwa Tuhan mampu menjauhkan seluruh malapetaka, termasuk wabah COVID - 19 ini (Bheri, 2020).

Upaya untuk membangun hubungan yang harmonis dengan tujuan agar Tuhan berkenan menyelamatkan dan menjauhkan manusia dari wabah COVID-19, juga terlihat nyata dilakukan oleh masyarakat Kalimantan Tengah, khususnya masyarakat Desa Tumbang Tambirah. Jika umat Kristen dan Islam melakukan ibadah secara pribadi di rumah masing-masing, berbeda dengan umat yang menganut kepercayaan agama suku yaitu agama Kaharingan yang melakukan ritual tolak bala atau yang juga mereka sebut Ritual Punduk Sahur dengan cara mengumpulkan orang banyak untuk terlibat di dalam ritual tersebut.

Ritual Punduk Sahur merupakan ritual yang bertujuan untuk mendapatkan kesejahteraan dan perlindungan dari leluhur dayak yang mereka percaya sebagai roh baik, terhadap marabahaya seperti wabah penyakit. Ritual ini merupakan tradisi turun temurun bagi suku dayak ngaju terlebih bagi mereka yang masih menganut agama Kaharingan. Sehingga tradisi ini masih sering dilakukan oleh masyarakat suku dayak ngaju yang berada di pelosok atau pedalaman, khususnya yang ada di Desa Tumbang Tambirah. Ritual atau upacara Punduk Sahur dilakukan dengan tujuan memanggil roh-roh yang dipercaya sebagai rohbaik atau roh leluhur atau yang disebut sahur, sesuai dengan keyakinan orang suku dayak ngaju. Leluhur atau roh baik akan diundang melalui ritual tersebut dengan perantara seorang Basir atau pemimpin ritual agama Kaharingan yang biasanya memiliki kemampuan berkomunikasi dengan para leluhur atau roh baik yang mereka percayai (Riwut, 2003).

Ritual Punduk Sahur yang dilaksanakan di Desa Tumbang Tambirah pada tanggal 23 Maret 2020 dilaksanakan atas dasar mufakat atau kesepakatan 
masyarakat wilayah setempat, melalui kebersamaan yang mendalam dan kesadaran untuk menjaga kesejahteraan dan kedamaian hidup masyarakat. Masyarakat akan secara sukarela memberikan bantuan atau dukungan baik berupa materi ataupun moral demi keberlangsungan ritual tersebut. Oleh karena itu, ritual Punduk Sahur tidak bisa tidak hanya melibatkan masyarakat setempat yang menganut agama Kaharingan, tetapi juga masyarakat yang menganut kepercayaan berbeda, seperti agama Islam dan termasuk juga agama Kristen. Keterlibatan dalam ritual Punduk Sahur di Desa Tumbang Tambirah dilakukan masyarakat tanpa melihat pada latar belakang agama atau keyakinan. Berdasarkan informasi dari salah satu warga Desa Tumbang Tambirah, seluruh masyarakat Desa Tumbang Tambirah, tanpa terkecuali orang Kristen, terlibat dalam ritual tersebut. Bagi masyarakat Desa Tumbang Tambirah ritual Punduk Sahur wajib dilaksanakan mengingat pada saat ini dunia sedang mengalami krisis di bidang kesehatan dikarenakan wabah COVID-19 yang sudah ditetapkan menjadi pandemi.

Jika dilihat dari sudut pandang Teologis, makayang seharusnya dilakukan oleh orang Kristen pada saat menghadapi wabah COVID-19 adalah dengan beriman secara penuh kepada Kristus dan membangun kehidupan spiritualnya dengan melakukan ibadah dan berdoa kepada Kristus untuk menjauhkan segala penyakit dan marabahaya, seperti yang di firmankan dalam kitab 1 Petrus 5:7 "Serahkanlah segala kekuatiranmu kepada-Nya, sebab Ia yang memelihara kamu." Namun pada praktiknya, orang Kristen di Desa Tumbang Tambirah tidak hanya melaksanakan ibadah dan berdoa kepada Kristus, tetapi juga melakukan dan terlibat dalam ritual agama Kaharingan, serta menaruh keyakinan dan harapannya bahwa leluhur atau roh baik akan menjaga dan memelihara mereka di tengah wabah COVID-19. Dengan mengadakan ritual Punduk Sahur mereka dapat berkomunikasi dengan roh baik atau leluhur dan memohon pertolongannya untuk menjauhkan mereka dari wabah COVID-19.

Melalui penjabaran fakta-fakta di atas, maka penulis tertarik untuk melakukan penelitian terhadap ritual punduk sahur di tengah wabah COVID-19 yang dilakukan oleh masyarakat Desa Tumbang Tambirah, khususnya terkait keterlibatan orang Kristen dalam ritual tersebut. Penelitian ini bertujuan untuk mengetahui dan mendeskripsikan bagaimana makna ritual Punduk Sahur di tengah wabah COVID-19 bagi masyarakat Desa Tumbang Tambirah, dan bagaimana keterlibatan orang Kristen dalam ritual Punduk Sahur di tengah wabah COVID-19 di Desa Tumbang Tambirah, Kalimantan Tengah.

\section{Kajian Pustaka}

Teori-teori yang dimuat terkait fokus penelitian adalah mengenai agama, totemisme dan ritus, serta kaitannya dengan Kristus dan kebudayaan. Menurut Durkheim, agama harus dipahami sebagai sesuatu yang memiliki cakupan yang luas. Ia tidak hanya tertuju atau berbicara tentang adanya kekuatan ilahi yang biasanya dikenal dengan tuhan atau "divinitas", melainkan juga apa yang biasanya dikenal oleh masyarakat primitif sebagai pemujaan terhadap "sesuatu yang spiritual."(Durkheim, 2005).

Pemahaman mengenai agama sebagai sesuatu yang riil dalam pandangan Durkheim, didapat hanya ketika manusia mampu menemukan karakter yang religius di dalam setiap kepercayaan dan ritus yang merupakan produk masyarakat. Melalui Kepercayaan dan ritus agama maka akan merperkuat ikatan-ikatan sosial di mana kehidupan kolektif bersandar. Dengan kata lain, 
hubungan antara agama dan masyarakat memperlihatkan saling ketergantungan yang sangat erat. Pada sisi lain ada yang berpendapat bahwa beragama hanya sebatas kepercayaan dan perbuatan yang berkaitan dengan hubungan manusia dengan kekuatan atau wujud gaib (Agus, 2007).

Totem merupakan bentuk pemujaan yang paling primitif dan merupakan bentuk kamejemukan dari kepercayaan. Melalui totem, yang merupakan sebuah simbol atau lambang, identitas suatu kelompok masyarakat (marga) dikenal dan ia merupakan sesuatu yang memiliki karakter religius dan tingkat kesakralan yang tinggi. Pemujaan terhadap totem merupakan pemujaan yang dilakukan individu dalam satu kesatuan kelompok, disebabkan karena setiap individu memiliki keyakinan yang sama bahwa totem merupakan suatu yang sakral (Mudji Sutrisno \& Hendar Putranto, 2005).

Menurut Durkheim, pemujaan terhadap totem merupakan penyembahan terhadap kekuatan yang anonim atau atuhan, namun kekuatan tersebut memiliki alam moral, di mana kekuatan tersebut hanya bisa dikenal melalui objek nyata yang dianggap sakral yaitu totem itu sendiri. Agama akan menjadi suatu yang riil dan bukan lagi sesuatu yang bersifat abstrak, ketika kekuatan religius yang ada pada totem dipahami sebagai hasil dari ciptaan kekuatan kolektif itu sendiri. Melalui ritus-ritus totemik mempersatukan individu dalam kegiatan bersama dengan satu tujuan bersama dan memperkuat kepercayaan, perasaan dan komitmen moral terhadap kehidupan kolektif (Durkheim, 2005). Menurut Victor Turner, ritus merupakan penampakan dari keyakinan religius. Kegiatan ritual tersebut memberi motivasi dan nilai yang paling dalam bagi orang-orang untuk melakukan dan mentaati tatanan sosial tertentu (Turner, 2011).
Melalui ritus, setiap penganut akan mengekspresikan kesunnguhan dan penghayatan mereka dengan bertumpu pada kesatuan emosional keyakinan. Ilahilah yang diyakini menghuni alam gaib diusahakan agar menjadi lebih kongkrit dan kemudian dikonsepsikan manusia dengan berbagai hal (Rada, 2001). Ritual atau ritus yang diadakan oleh suatu masyarakat merupakan penampakan dari keyakinan religius. Reitual yang dilakukan tersebut mendorong orangorang untuk melakukan dan mentaati tatanan sosial tertentu (Turner, 2011).

Kristus dan kebudayaan adalah suatu fenomena yang sampai sekarang ini menjadi pro dan kontra di kalangan orang Kristen. Hali ini terjadi karena di kalangan umat Kristen terdapat ratusan denominasi, sekte dan ajaran pemujaan yang berbeda (Suriani, 2008), namun menurut $\mathrm{H}$. Richard Niebuhr ada lima jenis tipologi Kristus dan kebudayaan (Niebuhr, 1956), yaitu: Pertama, sikap radikal: Kristus menentang kebudayaan, bagi orang Kristen jelas dikatakan di dalam Matius 6:24 dan I Yohanes 2:15 bahwa tidak dapat mengabdi kepada dua Tuhan. Sikap tersebut terlihat bagaimana orang Kristen yang mengasingkan diri dari masyarakat dan kebudayaan yang ada.

Kedua, sikap akomodasi: Kristus milik kebudayaan, sikap tersebut melihat kebudayaan dalam terang Allah dan kebudayaan adalah karunia dari Allah; Ketiga, sikap perpaduan: Kristus di atas kebudayaan, sikap perpaduan memiliki persamaan dengan akomodasi yang memilih antara Kristus dan Kebudayaan. Kristus relevan dengan kebudayaan, tetapi Kristus juga Tuhan di atas kebudayaan. Brownlee menjabarkan bahwa Kristus relevan dengan kebudayaan, meskipun demikian Ia tetap Tuhan atas kebudayaan. Kebudayaan berasal dari Allah dan dari manusia, oleh sebab itu kebudayaan perlu dilihat dalam terang ilmu pengetahuan dan penyataan Tuhan (Brownlee, 2011). 
Keempat, sikap dualis: Kristus dan kebudayaan dalam paradoks, orangorang dualis pada dasarnya sama dengan kaum radikal, mereka menganggap bahwa sumber dan akar dosa adalah kebudayaan tetapi kemudian mereka menyadari bahwa manusia tidak dapat lepas dari kebudayaan. Kaum ini juga mengetahui bahwa ia termasuk dalam kebudayaan itu dan tidak dapat keluar dari padanya, dan beranggapan bahwa Allah menyokongnya dalam kebudayaan itu.

Kelima. sikap pembaharuan: Kristus memperbaharui kebudayaan, sikap pembaharuan ini mencampur pemahaman dari aliran yang lain, yaitu sikap radikal, akomodasi, dualis, dan perpaduan kemudian dikembangkan sesuai dengan kebutuhan masyarakat dan berdasarkan iman kepada Kristus. Jadi, kaum ini menyetujui perbedaan antara Allah dalam Kristus dengan pekerjaan manusia dalam kebudayaan. Tetapi mereka tidak memisahkan diri dari kehidupan religius dengan kebudayaan dan menjauhi lembaga masyarakat. Karena Lembaga masyarakat tidak hanya mencegah kejahatan tetapi juga mengembangkan kebaikan.

\section{METODE}

Dalam penelitian ini pendekatan yang digunakan adalah metode kualitatif, yaitu sumber data yang digunakan tidak hanya pendapat yang disampaikan oleh seseorang (melalui wawancara), tetapi dapat pula dari sumber-sumber tertulis yang diinterpretasikan. Jenis penelitian yang digunakan adalah deskriptif. yang bermaksud mendeskripsikan sejumlah variabel yang berkenaan dengan masalah dan unit yang diteliti (Samiyono, 2008). Tujuannya adalah menjelaskan secara sistematis, faktual, dan akurat mengenai fakta-fakta, sifat-sifat, serta hubungan antar fenomena yang diteliti, sehingga pemilihan metode ini sangat tepat dan sesuai dengan penelitian yang dilakukan, yaitu penelitian terhadap sikap, perilaku, dan proses sosial, khususnya yang berhubungan dengan Keterlibatan Orang Kristen terhadap Ritual Punduk Sahur di Desa Tumbang Tambirah, Kalimantan Tengah.

Teknik pengumpulan data dalam penelitian ini ialah dengan melakukan observasi yaitu pengamatan dan pencatatan yang sistematis terhadap gejala-gejala yang muncul dalam penelitian (Gulo, 2002). Peneliti melakukan observasi non partisitipatif yaitu tidak terlibat secara langsung dalam kegiatan namun memperoleh gambaran secara umum terkait ritual Punduk Sahur melalui komunikasi dan data yang diperoleh melaui media komunikasi, telpon dan whatsapp. Lalu dengan wawancara yang merupakan teknik pengumpulan data yang digunakan peneliti untuk mendapatkan keteranganketerangan lisan melalui percakapan dan tatap muka secara langsung dengan orang yang dapat memberikan keterangan (informan) kepada peneliti agar peneliti mendapatkan data primer yang dibutuhkan (Mardalis, 2003). Peneliti memilih beberapa informan yang memiliki pengaruh di tempat yang akan diteliti, diantaranya Basir (Pemimpin ritual), Pendeta dan pejabat gereja, jemaat gereja yang melaksanakan Ritual Punduk Sahur itu sendiri.

Kemudian dengan studi dokumentasi, dimana dokumentasi adalah ditujukan untuk memperoleh data langsung dari tempat penelitian meliputi: buku-buku yang relevan, peraturanperaturan, laporan kegiatan, foto-foto, film dokumenter data yang relevan penelitian (Riduawan, 2006). Pada penelitian ini peneliti mengumpulkan semua data atau bahan pustaka, hasil dokumen yang terkumpul yang berkaitan dengan bagaimana proses penyelenggaraan 
Ritual Punduk Sahur di Tengah wabah COVID-19 dan Faktor keterlibatan orang Kristen terhadap Penyelenggaraan Ritual Punduk Sahur di Tumbang Tambirah, Kalimantan Tengah dicatat, untuk selanjutnya disempurnakan penulisannya setelah peneliti kembali dari lapangan. Peneliti juga menggunakan triangulasi data. Triangulasi diartikan sebagai teknik pengumpulan data yang bersifat menggabungkan dari berbagai teknik pengumpulan data dan sumber data. Dalam hal triangulasi, mengutip pendapat Susan Stainback yang menyatakan bahwa tujuan dari triangulasi bukan untuk mencari kebenaran tentang beberapa fenomena dan lebih pada peningkatan pemahaman peneliti terhadap apa yang telah ditemukan (Sugiono, 2018).

Dalam proses analisis data, peneliti mengolah dengan cara mencari keselarasan dan menata hasil catatan dari lapangan untuk memperoleh suatu pemahaman. Data hasil wawancara dengan informan bersifat kualitatif, sehingga memerlukan interpretasi dari peneliti. Interpretasi tersebut dapat dilakukan ketika semua data mengenai topik permasalahan telah terkumpul. Peneliti juga melakukan pengecekan ulang dengan semua informan, bila menurut peneliti data yang didapat mempunyai kekurangan atau kesalahan. Hal ini akan mendukung keaslian data yang berhubungan dengan topik penelitian (Nuraini, 2012).

\section{PEMBAHASAN}

Sebelum pembahasan mendalam mengenai pelaksanaan ritual Punduk Sahur yang dilakukan oleh masyarakat Desa Tumbang Tambirah, terlebih dahulu penulis ingin memaparkan teknis pelaksanaan ritual tersebut. Proses pelaksanaan ritual Punduk Sahur secara umum tidaklah berbeda dengan proses pelaksanan ritual Punduk Sahur yang biasanya dilakukan masyarakat sebelum adanya wabah COVID-19. Tandak atau isi doa pada ritual Punduk Sahur harus disesuaikan dengan tujuan ritual Punduk Sahur diadakan. Apabila semua syaratsyarat dalam ritual Punduk Sahur sudah disiapkan, maka barulah kemudian masyarakat melaksanakan ritual Punduk Sahur yang dipimpin oleh Pisur. Semua perlengkapan dan syarat-syarat ritual yang sudah dipersiapkan sehari sebelum ritual diadakan, diletakkan di salah satu ruangan dan Pisur maupun masyarakat desa yang hadir akan duduk mengelilingi perlengkapan dan syarat-syarat ritual tersebut. Setelah itu, barulah Pisur memulai ritual Punduk Sahur dengan cara menawur behas atau menabur beras dilakukan dengan tujuan berkomunikasi dengan roh leluhur. Seraya menabur beras, Pisur akan memanjatkan permohonan atau doa-doa dalam bahasa sangen agar roh leluhur membantu menjauhkan masyarakat desa dari wabah COVID-19 dan secara langsung menyerahkan atau mempersembahkan sesajen kepada roh leluhur.

Setelah Pisur selesai memanjat doa dengan menawur, barulah kemudian pinggan sahur yang berisi tambak atau penduduk yang sudah dibungkus dengan kain berwarna kuning digantung di balai Kaharingan atau di dalam rumah, atau biasanya dibagian sudut belakang pintu rumah. Proses ini dinamakan dengan Manggantung Pinggan Sahur yang merupakan tanda masyarakat sudah memanjatkan permohonan kepada roh leluhur. Selesai Manggantung Pinggan Sahur, Pisur akan membuka hamburuan yang dibungkus dengan kain putih, dan melihat pertanda yang diberikan oleh roh leluhur pada hambaruan tersebut.

Apabila pada butir beras yang menjadi simbol hambaruan terdapat tanda berwarna putih susu atau yang diistilahkan dengan hariten, maka hal itu merupakan pertanda baik yaitu roh 
leluhur telah mendengarkan permohonan dan melindungi warga desa Tumbang Tambirah atau yang diistilahkan dengan "hariten halewu benteng, barintih duan upu tundu." Daun sawang dan hambaruan yang telah memberikan pertanda baik tadi, akan dikembalikan kepada masing-masing anggota keluarga dan wajib digantung di dalam rumah atau di luar rumah, hal ini menjadi tanda bahwa masyarakat desa Tumbang Tambirah sudah memanjatkan permohonan atau doa kepada roh leluhur dan menjadi tanda bahwa roh leluhur akan melindungi anggota keluarga dari wabah COVID-19. Setelah proses ritual Punduk Sahur selesai, maka sesajen yang sudah didoakan dipersembahkan kepada leluhur, biasanya akan dijamu bersamasama oleh masyarakat desa Tumbang Tambirah yang hadir dalam ritual, dengan ketentuan sesajen tersebut terlebih dahulu disisihkan dan diletakkan di Pasah Patahu atau rumah tempat berdiamnya roh leluhur.

\section{Ritual Punduk Sahur di Tengah Wabah COVID-19 di Desa Tumbang Tambirah}

Suku Dayak Ngaju yang ada di Desa Tumbang Tambirah sangat menjunjung tinggi nilai-nilai yang tertuang dalam agama Kaharingan. Artinya, jika ingin mengenal kehidupan masyarakat Dayak Ngaju baik dalam ranah sakral maupun profan maka hal yang pertama kali harus dilakukan ialah dengan mengenal dan memahami nilai-nilai yang tertuang dalam Kaharingan sebagai identitas serta acuan untuk bertindak dan bersikap. Nilai-nilai inilah yang akan tetap dipelihara dan dijunjung tinggi oleh masyarakat suku Dayak Ngaju.

Namun, fenomena yang terjadi sampai saat ini ialah, kepercayaan atau Agama Kaharingan tersebut tidak diakui sebagai suatu agama (kepercayaan terhadap "Tuhan" seperti yang pada umumnya diyakini oleh agama-agama resmi), sehingga tidak jarang di antara penganutnya kemudian memilih untuk berpindah agama dengan berbagai alasan. Tidak hanya itu, mereka yang masih menganut Agama Kaharingan tidak jarang dianggap sebagai orangorang yang menyembah berhala karena kepercayaan mereka akan keberadaan roh-roh leluhur. Sedangkan menurut informasi dari salah penganut Agama Kaharingan di Desa Tumbang Tambirah, apa yang seringkali orang lain pahami tersebut merupakan pemahaman yang salah, karena bagi penganut Agama Kaharingan leluhur bukanlah berhala melainkan mereka adalah malaikat Ranying Hatalla Langit yang diberi kepercayaan untuk mengawasi dan menjaga kehidupan manusia. Pandangan yang salah terhadap agama Kaharingan tentu sajamengaburkanatau mengabaikan pengertian agama yang sebenarnya, seperti dalam pemahamannya Durkheim. Agama tidak boleh dipahami hanya dalam arti sempit yaitu keyakinan terhadap "Tuhan" di mana Durkheim sendiri tidak memilih untuk menggunakan istilah tersebut, karena jika agama hanya diidentikkan dengan penggunanaan kata atau istilah, maka apa yang diyakini oleh masyarakat primitif yang ada di Australia dan masyarakat Dayak Ngaju yang ada di Desa Tumbang Tambirah akan berada di luar ranah atau pengertian agama itu sendiri.

Dalam teorinya Durkheim memaparkan bahwa agama tidak bisa dipahami dalam arti sempit atau pemahaman yang terbatas pada "divinitas". Seperti yang juga dipahami oleh Karen Amstrong bahwa tidak semua agama bersifat theistik (Amstrong, 2009). Jadi, dapat disimpulkan bahwa apa yang menjadi keyakinan masyarakat Desa Tumbang Tambirah terhadap keberadaan Sahur tidaklah berada di luar ranah agama tetapi ia adalah agama itu sendiri yang di dalamnya terdiri dari ritus dan kepercayaan, yaitu kepercayaan kepada 
"sesuatu yang spiritual" dalam istilah Durkheim. "Sesuatu yang spiritual" bagi masyarakat suku Dayak Ngaju tidak hanya terbatas pada Ranying Hatalla Langit, tetapi juga leluhur dan apa-apa yang terdapat di dalam alam semesta.

Kaharingan sebagai budaya dan kepercayaan masyarakat suku Dayak Ngaju mengajarkan nilai-nilai yang sampai saat ini tertanam dalam diri, sikap, tindakan dan pola pikir dari setiap individu. Oleh karena itu, tidak heran apabila nilai-nilai yang dipercaya merupakan amanah dari Ranying Hatalla Langit melalui perantara roh leluhur masih tetap terpelihara dan dilakukan hingga sekarang. Bagi masyarakat Desa Tumbang Tambirah secara umum atau bagi mereka yang menganut kepercayaan di luar Agama Kaharingan, pelaksanaan ritual Punduk Sahur dipandang sebagai upaya untuk melestarikan kebudayaan Suku Dayak Ngaju dan menjaga tradisi leluhur. Namun sadar atau tidak, kebudayaan Suku Dayak Ngaju merupakan kebudayaan yang berakar di dalam Agama Kaharingan itu sendiri, sehingga bisa dikatakan nilai Kaharingan akan tetap ada dan tertanam dalam diri setiap individu sekalipun mereka menganut kepercayaan di luar Agama Kaharingan.

Hal ini didukung oleh fakta bahwa Agama Kaharingan adalah agama yang terlebih dahulu hadir (agama pribumi) dibanding agama-agama resmi karena ia merupakan warisan leluhur yang selalu menumbuhkan rasa tanggung jawab dan penghormatan yang tinggi dari setiap individu yang menjadi bagian dalam masyarakat Dayak Ngaju, khususnya yang ada di Desa Tumbang Tambirah. Oleh karena itu, pada bagian ini akan dilakukan analisa tentang bagaimana nilai-nilai Agama Kaharingan masih diterapkan dalam kehidupan masyarakat Desa Tumbang Tambirah. Nilai-nilai tersebut terlihat diterapkan dalam dua ranah kehidupan masyarakat, baik dalam ranah sakral maupun profan.

Dalam ranah kehidupan sakral, nilai-nilai Agama Kaharingan berusaha mengatur hubungan antara manusia dengan alam, leluhur dan Ranying Hatalla Langit sebagai penguasa tertinggi baik di pantai danum sangiang dan di pantai danum kalunen. Maka dapat disimpulkan bahwa hal-hal yang tergolong atau dikategorikan sakral dalam pemahaman suku Dayak Ngaju, khususnya yang ada di Desa Tumbang Tambirah ialah: (1) segala sesuatu yang berhubungan dengan ketetapan dari Ranying Hatalla Langit (2) roh-roh leluhur (2) alam semesta (3) ritus-ritus atau upacara keagamaan. Ritus atau ritual merupakan bentuk usaha masyarakat suku Dayak Ngaju di Desa Tumbang Tambirah untuk mengatur hubungan antara manusia dan Ranying Hatalla Langit, manusia dan alam, manusia dan sesamanya.

Ada banyak ritual-ritual Agama Kaharingan yang masih dilakukan oleh masyarakat di Desa Tumbang Tambirah, salah satunya ialah ritual Punduk Sahur. Melalui ritual Punduk Sahur akan terlihat jelas karakter-karakter religius dan nilainilai Kaharingan terangkum menjadi satu di dalamnya. Tata cara atau proses dalam ritual Punduk Sahur merupakan penerapan nilai-nilai Kaharingan yang berfungsi mengatur kehidupan masyarakat (Ahmad Yunus dan Sumantri Sastrosuwondo, 1985) dalam konteks ini masyarakat Desa Tumbang Tambirah, tidak hanya dalam ranah sakral tetapi juga profan (kehidupan sosial).

Ritual-ritual Agama Kaharingan termasuk ritual Punduk Sahur merupakan ungkapan dari kepercayaan, sikap dan tingkah laku yang dimotivasi oleh keyakinan (Ugang, 1983), yaitu keyakinan akan adanya "kuasa tertinggi" yang termanifestasi pada keberadaan roh leluhur yang menguasai dan melindungi kehidupan manusia. Dengan adanya 
keyakinan tersebut, maka di dalam diri setiap individu akan tumbuh rasa tanggung jawab untuk mengatur hubungannya dengan roh-roh leluhur, seraya melestarikan kebudayaan Suku Dayak Ngaju yang ada di Desa Tumbang Tambirah. Sehingga identitas kesukuan mereka semakin dipererat ketika ritual tersebut tetap dilakukan terlebih dalam situasi dunia yang sedang dilanda wabah COVID-19.

Melalui ritual Punduk Sahur masyarakat Desa Tumbang Tambirah merasakan dua hal yang sangat mempengaruhi psikis mereka dan menyentuh sisi moral dalam diri mereka, di mana melalui ritual tersebut mereka telah menunaikan tanggung jawab moral masing-masing individu. Di satu sisi, mereka telah menunaikan tanggung jawab moralnya terhadap "kuasa tertinggi", baik terhadap Ranying Hatalla Langit dan leluhur dayak, serta di satu sisi mereka telah menunaikan tanggung jawab moralnya sebagai bagian dari masyarakat suku Dayak Ngaju, khususnya masyarakat Desa Tumbang Tambirah untuk tetap melestarikan adat dan kebudayaan.

Hal ini membuktikan bahwa praktik keagamaan melalui itual Punduk Sahur yang dilakukan di tengah wabah COVID-19 dapat menciptakan solidaritas sosial atau identitas sosial masyarakat Desa Tumbang Tambirah sebagai suku Dayak Ngaju. Pernyataan ini sesuai dengan hasil penelitian terkait faktor kebudayaan dan sosial yang mendorong keterlibatan masyarakat Desa Tumbang Tambirah secara umum. Fakta ini juga sesuai dengan teori Durkheim yang menyatakan bahwa ritual-ritual keagamaan merupakan kegiatan yang berfungsi mempererat ikatan sosial masyarakat dengan bersandar dan bergantung pada hal-hal yang sakral (Durkheim, 2005).
Dalam ranah kehidupan sakral, seperti halnya ritual Punduk Sahur merupakan ritual yang tertuju pada totem-totem suku Dayak Ngaju secara umum. Kepercayaan kepada roh-roh leluhur Dayak, merupakan totem bagi masyarakat di Desa Tumbang Tambirah dan oleh karena itu leluhur memiliki tingkat kesakralan yang tinggi. Leluhur yang menjadi totem dipercaya sebagai orang sakral yang menjaga kehidupan manusia dan membantu mereka berkomunikasi dengan Ranying Hatalla Langit. Leluhur inilah yang disebut sebagai Sahur dan ia akan berada atau berdiam di setiap daerah (desa) kediaman suku Dayak Ngaju, salah satunya di Desa Tumbang Tambirah.

Berdasarkan pembahasan Durkheim dalam teorinya, totem merupakan pemujaan yang paling primitif. Baginya totem tidak hanya sebagai tanda pengenal sebuah kelompok masyarakat melainkan ia juga memiliki tingkat kesakralan yang tinggi. Pemujaan terhadap totem juga erat hubungannya dengan pemujaan kepada roh leluhur di mana akan ada suatu objek tertentu yang dipilih tempat di mana wujud-wujud roh leluhur terindividualisasi atau tempat dimana roh leluhur berdiam (Durkheim, 2005), yang biasa disebut oleh suku Dayak Ngaju adalah Pasah Patahu.

Dalam hubungannya dengan masyarakat Dayak Ngaju yang ada di Desa Tumbang Tambirah, khususnya dalam ritual Punduk Sahur, kepercayaan terhadap roh leluhur bisa dikatakan sebagai bentuk pemujaan terhadap totem. Leluhur sebagai malaikat Ranying Hatalla Langit dipercaya hadir di tengahtegah kehidupan manusia hanya saja tidak bisa dilihat secara kasat mata. Namun, walaupun kehadiran leluhur tidak bisa dilihat secara kasat mata, ada suatu objek tertentu tempat di mana leluhur menghadirkan atau mewujudkan 
dirinya, yaitu dalam bentuk batu-batu yang biasanya terletak di bawah pasah patahu.

Penghormatan terhadap roh leluhur sebagai orang sakral menimbulkan respek yang tinggi di dalam diri setiap individu. Dengan adanya keyakinan terhadap keberadaan roh leluhur di tengah-tengah kehidupan masyarakat Desa Tumbang Tambirah, maka secara psikis masyarakat merasakan bahwa kehidupan mereka akan aman, tentram dan jauh dari segala marabahaya, seperti bahaya wabah COVID-19. Dalam hal ini roh leluhur merupakan orang sakral yang ditakuti, dihormati dan dipuja oleh masyarakat Desa Tumbang Tambirah.

Bagi masyarakat Dayak Ngaju yang ada di Desa Tumbang Tambirah, kehidupan sakral sangat mempengaruhi kehidupan profan. Mematuhi amanat Ranying Hatalla Langit melalui perantara roh leluhur merupakan bagian dari kehidupan sakral di mana ia akan sangat mempengaruhi kehidupan profan manusia, baik pekerjaan, kesuksesan, kesehatan, kehidupan keluarga, kesejehteraan, kedamaian baik di pantai danum kalunen atau kelak di pantai danum sangiang. Ketika masyarakat Desa Tumbang Tambirah telah menerapkan nilai-nilai Kaharingan, baik yang mengatur hubungan manusia dengan Ranying Hatalla Langit, sesama dan alam, maka mereka meyakini bahwa kehidupan selama di dunia dan di sorga akan diberkahi, diberi kesejahteraan, kedamaian dan keselamatan dari berbagai marabahaya termasuk bahaya wabah COVID-19.

Jadi, dalam pandangan suku Dayak Ngaju di Desa Tumbang Tambirah ada suatu ketergantungan yang sangat intens antara manusia terhadap roh leluhur. Ketergantungan itu ada disaat mereka meyakini bahwa roh leluhur adalah orang-orang sakral yang diberi kekuasaan oleh Ranying Hatalla Langit untuk menjaga kehidupan manusia dan yang juga diberi kewenangan untuk menghukum siapapun yang tidak melaksanakan apa yang telah diamanatkan oleh Ranying Hatalla Langit atau dikenal dengan istilan nyaranta. Kepercayaan dan respek yang tinggi terhadap roh leluhur pada akhirnya membentuk suatu pemujaan yang wajib dilakukan oleh masyarakat Dayak Ngaju di Desa Tumbang Tambirah. Pemujaan tersebut dikhususkan kepada Sahur melalui pelaksanaan ritual Punduk Sahur. Dalam pelaksanaan ritual Punduk Sahur, ada beberapa hal yang dikategorikan sebagai hal yang memiliki nilai-nilai sakral menurut paham masyarakat Desa Tumbang Tambirah yang masih memeluk Agama Kaharingan.

Hal-hal yang dikategorikan sakral merupakan hal-hal yang selalu tertuju pada roh leluhur sebagai orang yang memiliki tingkat kesakralan tertinggi selain Ranying Hatalla Langit. Adapun hal-hal yang tergolong sakral dalam ritual Punduk Sahur, ialah: a) Bahasa Sangiang atau Sangen yang biasanya digunakan dalam ritual Punduk Sahur. Bahasa Sangen hanya boleh diucapkan ketika Pisur atau Basir melaksanakan ritual Punduk Sahur dalam rangka berkomunikasi atau berhubungan dengan roh leluhur; b) Pondok Patahu atau Pasah Patahu yang digunakan untuk meletakkan sesajen dan dipercayai sebagai tempat berdiamnya para Sahur atau roh leluhur; c) Sesajen bagi suku Dayak Ngaju di Desa Tumbang Tambirah merupakan hal yang sakral. Cara-cara untuk memasak sesajen merupakan ketentuan yang diamanatkan oleh roh leluhur melalui perantara Pisur pada saat manenung; d) Makananmakanan tertentu yang biasanya tidak boleh dikosumsi oleh masyarakat setelah ritual Punduk Sahur selesai dilaksanakan

Melihat kembali pemahaman Durkheim dalam teorinya mengenai pembagian kehidupan manusia menjadi dua ranah yaitu yang sakral dan profan, 
maka kita dapat membandingkan bagaimana pengertian sesuatu yang sakral menurut Durkheim dan menurut pandangan masyarakat suku Dayak Ngaju yang ada di Desa Tumbang Tambirah. Bagi Durkheim sesuatu dapat dikatakan sakral tidak selalu tertuju pada sosok pribadi tertentu. Adapun hal-hal yang tergolong sakral dalam pemahaman Durkheim ialah seperti; dewa-dewi, rohroh, ritus-ritus, batu-batu, kayu, mata air, pohon, dsb (Durkheim, 2005).

Meninjau pemahaman mengenai hal yang sakral baik dari pemahaman Dukheim dan pemahaman masyarakat Desa Tumbang Tambirah, maka dapat ditarik satu persamaan bahwa apa yang dipahami sebagai yang sakral yaitu mencakup segala sesuatu yang biasanya bisa dijadikan totem, di mana totem tersebut memilih objek tertentu sebagai wujud kongkritnya. Ketika masyarakat Desa Tumbang Tambirah memiliki totem yaitu roh leluhur mereka sendiri, maka disitulah mereka memiliki keyakinan bahwa segala sesuatu yang berhubungan dengan roh leluhur adalah sakral yang selalu dipagari oleh larangan-larangan atau pali agar sesuatu yang sakral tersebut tidak dicemari oleh hal-hal yang profan.

Melihat pemahaman mengenai hal yang sakral baik dari pemahaman Dukheim dan pemahaman masyarakat Desa Tumbang Tambirah, maka dapat ditarik satu persamaan bahwa apa yang dipahami sebagai yang sakral yaitu mencakup segala sesuatu yang biasanya bisa dijadikan totem, di mana totem tersebut memilih objek tertentu sebagai wujud kongkritnya. Totem memiliki karakter religius karena ia mengklasifikasikan segala sesuatu menjadi dua ranah yaitu yang sakral dan yang profan. Ketika masyarakat Desa Tumbang Tambirah memiliki totem yaitu roh leluhur mereka sendiri, maka disitulah mereka memiliki keyakinan bahwa segala sesuatu yang berhubungan dengan roh leluhur adalah sakral yang selalu dipagari oleh larangan-larangan atau pali agar sesuatu yang sakral tersebut tidak dicemari oleh hal-hal yang profan. Sebagai bentuk ekspresi dari rasa takut dan penghormatan yang tinggi, maka mereka melaksanakan pemujaan atau ritual.

Ritual Punduk Sahur sebagai bentuk usaha masyarakat Desa Tumbang Tambirah untuk melindungi dirinya dari wabah COVID-19, tentu saja melibatkan masyarakat desa secara umum dalam pelaksanaannya tanpa melihat perbedaan agama. Dari hasil penelitian, ada dua alasan yang dikemukakan oleh para informan terkait keterlibatan mereka di dalam ritual Punduk Sahur.

Adapun dua alasan keterlibatan tersebut ialah: 1) Penghormatan yang tinggi dan keyakinan yang kuat akan adanya keberadaan roh leluhur sebagai utusan Ranying Hatalla Langit yang diberi kewenangan untuk menjaga, memberikan ketentraman, kedamaian dan keselamatan di desa yang mereka tempati. Tidak hanya itu, masyarakat Desa Tumbang Tambirah menyakini bahwa mereka dapat memanjatkan permohonan atau bernazar kepada roh leluhur untuk melindungi mereka dari wabah COVID-19; 2) Rasa solidaritas yang tinggi sebagai masyarakat Dayak Ngaju yang ada di Desa Tumbang Tambirah menuntut adanya tanggung jawab setiap individu untuk terlibat di dalam pelaksanaan ritual Punduk Sahur. Sebagai bagian dari masyarakat Desa Tumbang Tambirah, keterlibatan setiap individu dalam pelaksanaan ritual merupakan cara untuk mengekspresikan rasa kekeluargaan dan wujud tanggung jawab moral terhadap masyarakat suku Dayak Ngaju di Desa Tumbang Tambirah.

Jadi dapat disimpulkan, ketika setiap individu meyakini bahwa adanya Ranying Hatalla Langit dan rohleluhuryang menguasai hidup mereka, maka disitulah 
terbentuk suatu kekuatan kolektif yang kemudian menciptakan ide-ide tentang bagaimana suatu yang sakral tersebut harus dihormati dan dipuja. Tanggung jawab moral yang menjadi alasan dalam keterlibatan setiap individu, merupakan bentuk respek yang tinggi terhadap masyarakat. Seperti yang dikatakan Durkheim dalam teorinya, bahwa respek terhadap "sesuatu yang spiritual" sama dengan respek individu terhadap masyarakatnya (Durkheim, 2005). Maka, tidak heran apabila berdasarkan otoritas moral setiap individu mematuhi berbagai aturan dan larangan yang pada dasarnya dibuat oleh masyarakat itu sendiri dengan bertumpu pada hal-hal yang sakral. Dengan munculnya respek baik terhadap yang sakral atau terhadap masyarakat, maka disitulah tercipta suatu kekuatan moral yang tidak lain adalah kekuatan kolektif.

Pelaksanaan ritual Punduk Sahur di tengah wabah COVID-19 merupakan bukti nyata bahwa masyarakat Desa Tumbang Tambirah sangat menjunjung tinggi kehidupan dalam ranah sakral, sehingga mereka percaya kehidupan mereka di dunia atau dalam ranah profan akan berjalan dengan baik dan mereka akan terhindar dari ancaman bahaya wabah COVID-19. Ide mengenai segala sesuatu yang sakral, menuntut masyarakat untuk menciptakan berbagai larangan atau pantangan dalam ritual yang berfungsi memisahkan hal yang profan dari yang sakral dan untuk mempertegas bahwa hal yang sakral sangat berkuasa atas kehidupan manusia, dalam arti bahwa ia sangat menentukan keberhasilan, kesejahteraan, kedamaian dan keselamatan manusia selama hidup di dunia yang penuh tantangan dan acaman.

Segala jenis pantangan atau larangan inilah yang dalam pemahaman Durkheim disebut sebagai pemujaan negatif. Jika pantangan atau larangan tersebut dilanggar pada saat melakukan ritual Punduk Sahur, maka mereka meyakini bahwa roh leluhur akan marah dan mendatangkan hukuman bagi manusia yang melanggarnya yang distilahkan dengan sebutan Nyaranta. Pada saat individu terlibat dalam suatu ritual, maka larangan atau pantangan yang dipatuhi akan mengikat setiap individu dalam satu keyakinan yang sama yaitu bahwa hal-hal yang sakral harus diisolasi dari hal-hal profan.

Penghormatan terhadap hal-hal yang bersifat sakral dan penghormatan terhadap masyarakat merupakan suatu bentuk kekuatan moral yang tidak lain adalah kekuatan kolektif yang disalurkan ke dalam diri setiap individu. Ritual Punduk Sahur merupakan bentuk pemujaan yang dilakukan masyarakat Desa Tumbang Tambirah dalam rangka mengafirmasikan kepercayaan mereka dan menenunaikan tanggung jawab moral setiap individu baik terhadap masyarakat suku Dayak Ngaju dan terhadap apa yang mereka imani yaitu hal-hal yang sakral dalam pamahaman mereka.

\section{Keterlibatan Orang Kristen dalam Ritual Punduk Sahur di Tengah Wabah Covid-19 di Desa Tumbang Tambirah}

Ritual Punduk Sahur di tengah wabah COVID-19 melibatkan hampir 90\% masyarakat di Desa Tumbang Tambirah. Tidak hanya umat Kaharingan, tetapi juga umat agama lainnya seperti Kristen, Katolik dan Islam. Bagi masyarakat desa Tumbang Tambirah yang masih memeluk agama Kaharingan, keterlibatan dalam ritual Punduk Sahur merupakan suatu kewajiban. Namun, bagi mereka yang tidak lagi menganut agama Kaharingan, keterlibatan dalam pelaksanaan ritual Punduk Sahur merupakan suatu tanggung jawab moral sebagai satu suku dan budaya. 
Keterlibatan orang Kristen dalam ritual Punduk Sahur membuktikan bahwa orang Kristen masih sangat menghargai dan menghormati tradisi leluhur atau kebudayaan yang tertuang dalam nilainilai agama Kaharingan. Inilah yang menjadi salah satu faktor pendorong mengapa sebanyak kurang lebih 70\% orang Kristen di desa Tumbang Tambirah terlibat aktif dalam ritual Punduk Sahur. Walaupun dalam peraturan hukum Gereja Kalimantan Evangelis (GKE) terdapat peraturan tertulis terkait keterlibatan jemaat Kristen dalam ritualritual Kaharingan yang juga merupakan kebudayaan bagi masyarakat suku Dayak. Namun, juga memiliki nilai-nilai yang bertentangan dengan peraturan gereja.

Selain faktor kebudayaan, faktor sosial pun menjadi pendorong bagi orang Kristen untuk terlibat dalam ritual Punduk Sahur. Berlandaskan pada tradisi gotong royong, masyarakat Desa Tumbang Tambirah memiliki ikatan sosial yang erat sebagai masyarakat suku Dayak Ngaju, terbukti melalui pelaksanaan ritual Punduk Sahur yang dilaksanakan berdasarkan kesepakatan bersama. Pelaksanaan ritual Punduk Sahur di Desa Tumbang Tambirah juga didukung oleh pihak gereja karena gereja merupakan bagian dari masyarakat Dayak Ngaju yang ada di Tumbang tambirah, sehingga dalam pelaksanaan ritual tersebut orang Kristen merasa wajib untuk hadir dan berpartisipasi dengan memberikan bantuan baik secara materi, moral, maupun tenaga. Hal ini jelas membuktikan bahwa keterlibatan orang Kristen dalam ritual Punduk Sahur tidak lepas dari tanggung jawab moralnya sebagai bagian dari masyarakat suku Dayak Ngaju di Desa Tumbang Tambirah dan memiliki kewajiban untuk tetap melestarikan dan melakukan tradisi leluhur.

Bahkan faktor Pendidikan pun tidak berpengaruh secara siginifikan terhadap tinggi rendahnya keterlibatan masyarakat, khususnya orang Kristen dalam ritual Punduk Sahur. Masyarakat desa Tumbang Tambirah yang terlibat dalam ritual Punduk Sahur dengan berbagai macam latar belakang Pendidikan, tetap memiliki satu pemahaman yang sama bahwa ritual tersebut merupakan tradisi leluhur yang harus dijaga dan dilestarikan terlebih dalam situasi masa kini di mana dunia sedang dilanda oleh bahaya wabah COVID-19, ritual Punduk Sahur merupakan ritual yang wajib diadakan untuk kepentingan bersama. Orangorang Kristen yang dituakan di Desa Tumbang Tambirah dan memiliki status Pendidikan yang cukup tinggi, yaitu tingkat sarjana justru menjadi pencetus dalam pelaksanaan ritual Punduk Sahur.

Sama halnya dengan faktor Pendidikan, faktor ekonomi yang juga tidak berpengaruh secara signifikan terhadap keterlibatan masyarakat, secara khusus orang Kristen dalam ritual Punduk Sahur di Desa Tumbang Tambirah. Orang-orang Kristen dari berbagai latar belakang tingkat perekonomian ikut berpatisipasi memberikan dukungan dana demi terlaksananya ritual Punduk Sahur. Bahkan pihak gereja pun ikut memberikan sumbangan dana, baik berupa uang ataupun sembako.

Keyakinan yang kuat akan keberadaan roh leluhur yang menjaga dan melindungi masyarakat Desa Tumbang Tambirah dari wabah COVID-19 menjadi salah satu faktor spiritual pertama yang mendukung keterlibatan orang Kristen dalam ritual Punduk Sahur. Faktor spiritual yang kedua yang mendukung keterlibatan orang Kristen dalam ritual Punduk Sahur ialah adanya dukungan yang diberikan oleh pihak gereja terhadap pelaksanaan Punduk Sahur dengan tetap mengikuti peraturan gereja terkait pelaksanaan ritual Kaharingan secara tertulis. Oleh karena itu, tidak bisa dipungkiri bahwa keterlibatan orang 
Kristen dalam ritual Punduk Sahur juga didukung oleh gereja dan didukung oleh satu pemahaman yang sama bahwa ritual tersebut dilakukan demi kepentingan dan keselamatan masyarakat Desa Tumbang Tambirah beserta keturunanketurunannya.

Jadi, dapat disimpulkan bahwa, yang pertama keterlibatan orang Kristen dalam ritual Punduk Sahur didasari atas kesadaran kolektif bahwa ritual Punduk Sahur merupakan kebudayaan dan tradisi yang harus tetap dijaga dan dilestarikan. Kedua, bahwa keterlibatan orang Kristen dalam ritual Punduk Sahur didasari atas keyakinan akan keberadaan roh leluhur yang dapat melindungi masyarakat Desa Tumbang Tambirah dari wabah COVID-19.

Berdasarkan faktor spiritual tersebut dan mengacu pada teori Richard Niebuhr tentang Kristus dan Kebudayaan, penulis menyimpulkan bahwa terdapat dua sikap yang dimiliki oleh orang Kristen di Desa Tumbang Tambirah terkait hubungan antara Kristus dan kebudayaan. Orang Kristen di Desa Tumbang Tambirah menilai Kristus dalam hubungannya dengan kebudayaan yaitu: Sikap yang pertama adalah dualis yang memahami Kristus dan kebudayaan dalam paradoks, karena kaum dualis mengakui pernyataan ilmu pengetahuan, hukum dan kasih karunia. Kaum ini juga mengetahui bahwa ia termasuk dalam kebudayaan itu dan tidak dapat keluar dari padanya, dan beranggapan bahwa Allah menyokongnya dalam kebudayaan itu (Niebuhr, 1956), Marthin Luther membedakan secara tajam kehidupan duniawi dan kehidupan rohani, ada dua kerajaan, yaitu : kerajaan Allah dan kerajaan manusia. Kerajaan Allah bersifat kasih karunia dan rahmat, sedangkan kerajaan manusia bersifat kemurkaan dan kekeransan (Brownlee, 2011).

Sikap yang kedua adalah akomodasi yaitu Kristus milik kebudayaan, Orang- orang yang memiliki sikap seperti ini adalah orang-orang Kristen bukan hanya dalam arti bahwa mereka menganggap dirinya sendiri sebagai orang yang beriman kepada Tuhan tetapi juga dalam arti bahwa mereka berupaya mempertahankan komunitas dengan orang-orang beriman lainnya (Niebuhr, 1956).

Dalam hubungannya dengan kebudayaan, orang Kristen di Desa Tumbang Tambirah berada pada sikap dualis. Di satu sisi, orang Kristen tidak bisa meninggalkan tradisi leluhur dalam ritual Punduk Sahur yang mereka yakini dapat melindungi mereka dari segala marabaya termasuk wabah COVID-19. Di satu sisi, berdasarkan pernyataan dari beberapa informan, mereka melihat bahwa keyakinan tersebut bertentangan dengan iman mereka, karena pada saat ritual Punduk Sahur dilakukan, tujuannya adalah bernazar dan memohon perlindungan dari roh leluhur bukan perlindungan dari Yesus Kristus yang diimani sebagai Tuhan dalam agama Kristen. Sehingga dengan sikap dualis ini, orang Kristen memiliki kecenderungan sulit untuk menentukan sikap yang tepat ketika iman mereka diperhadapkan dengan tradisi leluhur yang disatu sisi sangat dihargai dan masih dilakukan oleh masyarakat Desa Tumbang Tambirah.

Sikap kedua yang dimiliki oleh orang Kristen yang ada di desa Tumbang Tambarah dalam hubungan imannya kepada Kristus dan kebudayaan adalah sikap akomodasi yang melihat Kristus sebagai milik kebudayaan. Orang Kristen di desa Tumbang Tambirah tidak hanya melihat diri mereka sebagai orang-orang yang menaruh imannya kepada Yesus Kristus sebagai Tuhan, tetapi juga tetap berusaha menjaga keutuhan kehidupan sosial sebagai masyarakat suku Dayak Ngaju yang kaya akan tradisi dan kebudayaan, walaupun dengan latar belakang keyakinan yang berbeda-beda. 
Dalam hal ini, orang Kristen di Desa Tumbang Tambirah melihat bahwa kepercayaan kepada roh leluhur dalam pelaksanaan ritual Punduk Sahur sejalan dengan pemahaman bahwa Tuhan mendukung pekerjaan-perkerjaan baik yang mendatangkan kebaikan bagi kehidupan bersama. Oleh karena itu, orang-orang Kristen meyakini bahwa ritual Punduk Sahur adalah tradisi leluhur yang bertujuan membawa kebaikan bagi kehidupan masyarakat. Jadi, dapat disimpulkan, baik sikap dualis ataupun akomodasi, semuanya berangkat dari pemahaman orang Kristen di Desa Tumbang Tambirah bahwa ritual Punduk Sahur merupakan tradisi leluhur yang sarat akan nilai moral, sosial, budaya dan spiritual. Oleh karena itu, ritual Punduk Sahur sebagai tradisi leluhur tidak akan kehilangan eksistensinya dalam kehidupan masyarakat, bahkan dalam kehidupan orang Kristen yang ada di Desa Tumbang Tambirah.

Hal ini berbanding terbalik jika diperhadapkan dengan fenomena dari salah satu ritual masyarakat Dayak Bumate. Dalam sebuah penelitian serupa dengan menggunakan pendekatan sosioteologis yang berjudul "Ritus Pencurahan Darah Korban Binatang; Perjumpaan Injil Dengan Tradisi Manengeh Di Suku Dayak Bumate," Setiawan menyimpulkan bahwa Injil justru memiliki relevansi dengan ritus pencurahan darah dalam tradisi Manengeh suku Dayak Bumate. Terdapat point of contact antara ritus dengan Injil, melalui Yesus sebagai korban suku Bumate telah di bebaskan dari anasir-anasir jahat yang mengganggu dan memperbudak mereka dan rupanya di dalam ritus itu terdapat serpihan kebenaran yang dapat disusun ulang untuk membawa masyarakat Bumate kepada Yesus Kristus (Setiawan, 2020).

\section{SIMPULAN}

. Pada bagian ini penulis memberikan beberapa kesimpulan mengenai makna ritual Punduk Sahur bagi masyarakat Desa Tumbang Tambirah dan faktor penyebab keterlibatan orang Kristen dalam ritual Punduk Sahur di Desa Tumbang Tambirah, Kalimantan Tengah. Masyarakat Desa Tumbang Tambirah memaknai ritual Punduk Sahur sebagai bentuk tanggung jawab moral yang besar terhadap Ranying Hatalla Langit atau leluhur mereka. Melalui tanggung jawab moral tersebut mereka memiliki ikatan sosial yang erat sebagai bagian dari masyarakat suku Dayak Ngaju yang bertanggung jawab untuk menjaga dan melestarikan tradisi leluhur agar kehidupan mereka senantiasa aman dan dijauhkan dari segala marabahaya termasuk wabah COVID-19. Munculnya ancaman wabah COVID-19, justru semakin mempererat kesatuan pola pikir, sikap dan tindakan masyarakat Desa Tumbang Tambirah tanpa melihat perbedaan agama dalam mengatasi krisis tersebut melalui pelaksanaan ritual Punduk Sahur yang disepakati bersama dan diyakini untuk kebaikan bersama.

Ritual Punduk Sahur yang diyakini sebagai bagian dari kebudayaan dan tradisi leluhur juga menuntut keterlibatan orang Kristen yang juga bagian dari masyarakat suku Dayak Ngaju di Desa Tumbang Tambirah. Keterlibatan orang Kristen bahkan lebih besar dibandingkan keterlibatan masyarakat desa yang beragama Kaharingan, Khatolik dan Islam. Hal ini tentu disebabkan oleh beberapa faktor yang mendukung keterlibatan orang Kristen dalam ritual Punduk Sahur di tengah wabah COVID-19 di Desa Tumbang Tambirah. Pada satu sisi bertentangan dengan iman Kristen karena yang disembah dalam ritual tersebut bukan Yesus sebagai Tuhan yang diimani oleh Agama Kristen, melainkan roh leluhur. Namun, di lain sisi orang 
Kristen memandang bahwa ritual Punduk Sahur merupakan bagian dari kebudayaan dan tradisi leluhur yang harus dijaga dan dilestarikan oleh masyarakat Desa Tumbang Tambirah sebagai bagian dari suku Dayak Ngaju.

Selain itu juga, melihat pada tujuannya, orang Kristen memandang bahwa tidak ada hal yang salah dalam pelaksanaan ritual Punduk Sahur. Mereka meyakini bahwa ritual Punduk Sahur dilakukan dengan tujuan untuk kepentingan bersama yaitu untuk memperoleh keselamatan sehingga masyarakat Desa Tumbang Tambirah terhindar dari bahaya wabah COVID-19.

Kenyataan inilah yang membuat Penulis menarik suatu kesimpulan berdasarkan teori Richard Neibuhr, bahwa orang Kristen di Desa Tumbang Tambirah mengambil suatu sikap dualis dalam hubungan Kristus dan Kebudayaan. Dimana orang Kristen di Desa Tumbang Tambirah menganggap diri mereka tidak dapat dipisahkan dari kebudayaan dan bahwa Tuhan juga menyokong mereka dalam kebudayaan itu.

\section{SARAN}

Bagi Masyarakat Dayak dan Pemerintah: Masyarakat Dayak Ngaju di Desa Tumbang Tambirah harus memiliki kesadaran untuk tetap menjaga dan melestarikan kebudayaan Dayak. Partisipasi setiap individu dalam kegiatan-kegiatan yang berhubungan dengan kebudayaan Dayak sangat memberikan kontribusi yang besar bagi keutuhan masyarakat suku Dayak Ngaju. Tanpa adanya motivasi di dalam diri setiap individu untuk terlibat dalam pelestarian kebudayaan Dayak, maka masyarakat yang hidup pada generasi ke depan akan kehilangan identitasnya sebagai suku Dayak Ngaju.

Oleh karena itu, dalam hal ini tentu saja masyarakat membutuhkan bantuan atau peran dari pemerintah melalui dinas Pariwisata untuk mempromosikan kebudayaan Dayak dan mengembangkan berbagai macam kegiatan-kegiatan yang berhubungan dengan kebudayaan suku Dayak Ngaju. Penelitian selanjutnya diharapkan dapat mengkaji lebih dalam lagi mengenai nilai-nilai lainnya yang terdapat dalam ritual-ritual suku Dayak Ngaju, yang selanjutnya dapat dijadikan sumber ilmu dan wawasan dalam berbagai pengetahuan sosial.

\section{UCAPAN TERIMA KASIH}

Penulis mengucapkan terimakasih kepada pihak-pihak yang telah memberikan kesempatan mendukung dalam proses penelitian hingga pada tahap penulisan, khususnya kepada anggota tim penelitian dan seluruh civitas akademika IAKN Palangka Raya. Penulis juga menyampaikan terima kasih kepada seluruh masyarakat Desa Tumbang Tambirah, Kabupaten Gunung Mas, yang telah memberikan izin dan dukungan untuk melaksanakan penelitian. Penulis berharap, semoga melalui hasil penelitian ini dapat memberikan pengetahuan kepada civitas akademisi dan masyarakat tentang peran kebudayaan dalam kehidupanmasyarakatSukuDayakNgaju. Penulis juga menyadari bahwa penelitian ini masih jauh dari kata sempurna. Maka dari itu, penulis menerima kritik dan saran yang membangun agar kedepannya penulis dapat melakukan penelitian dengan lebih baik lagi. 


\section{DAFTAR ACUAN}

Agus, B. (2007). Agama Dalam Kehidupan Manusia. Jakarta: PT. Raja Grafindo.

Ahmad Yunus dan Sumantri Sastrosuwondo. (1985). Upacara Tradisional Daerah Kalimantan Tengah. Departemen Pendidikan dan Kebudayaan.

Amstrong, K. (2009). A History of God: Sejarah Tuhan. Bandung: Mizan Media Utama.

Bheri, M. H. (2020). Manusia Gentar Hadapi Virus Corona daripada Tuhan. Kompasiana. com. https://www.kompasiana.com/mateushubertusbheri9180/5e733011097f36 5d55670782/manusia-gentar-hadapi-virus-corona-daripada-tuhan?page=2

Brownlee, M. (2011). Tugas Manusia Dalam Dunia Milik Tuhan (Cetakan 6). Jakarta: BPK Gunung Mulia.

Durkheim, E. (2005). Sejarah Agama: The Elementary Form of The Religious Life (Inyak Ridwan Muzir (ed.); Terjemahan). IRCiSod.

Gulo, W. (2002). Metode Penelitian. Jakarta: Gramedia Widiarsana Indonesia.

Mardalis. (2003). Metode Penelitian-Suatu Pendekatan Proposal. Jakarta: Bumi Aksara.

Mudji Sutrisno \& Hendar Putranto. (2005). Teori-teori Kebudayaan. Jakarta: Kanisius.

Niebuhr, H. R. (1956). Kristus dan Kebudayaan. Jakarta: BPK Gunung Mulia.

Nuraini, S. (2012). Etnik Dayak Siang Murung. Jakarta: Kanisius.

Rada, N. H. (2001). Religi Orang Bukit. Jakarta: Yayasan Semesta.

Riduawan. (2006). Metode \& Teknik Penyusunan Tesis. Bandung: Alfabeta.

Riwut, N. (2003). Maneser Panatau Tatu Hiang. Palangka Raya: Pusakalima.

Samiyono, D. (2008). Metode Penelitian Sosial. Fakultas Teologi UKSW, Salatiga.

Setiawan, D. E. (2020). Ritus Pencurahan Darah Korban Binatang: Perjumpaan Injil Dengan Tradisi Manengeh di Suku Dayak Bumate. CARAKA, Jurnal Teologi Biblika Dan Praktika, 2(1), 1-15.

Sugiono. (2018). Metodologi Penelitian Kualitatif. Bandung: CV. Alfabeta.

Suriani, N. K. (2008). Tetegenan: Studi Terhadap Orang Kristen yang Menerima Sanksi Adat di GKPB Giri Suweca Katung-Bali. Universitas Kristen Satya Wacana, Salatiga.

Turner, V. witter. (2011). The Ritual Process: Structure and Anti-Structure. Aldine Transaction.

Ugang, H. (1983). Menelusuri Jalur-jalur Keluhuran. Jakarta: BPK Gunung Mulia. 